\title{
Observations on the Influence of Ration Quality on the Efficiency of Dietary Protein Utilisation for Milk Versus Meat Production in Friesians
}

\section{J B Moran*}

Profitable Dairy Systems, Kyabram, Victoria, Australia

*Corresponding Author: J B Moran, Profitable Dairy Systems, Kyabram, Victoria, Australia.
Received: April 15, 2021

Published: April 28, 2021

(C) All rights are reserved by J B Moran.

\section{Abstract}

From previously published research undertaken by the author over four years in two countries, the data generated in animal production studies on the beef or dairy performance of well fed and managed Friesian bulls or cows has been compared. The efficiency of utilisation of dietary protein retained in the carcasses of Friesian bulls fed one of two diets was monitored as was the efficiency of dietary protein for milk protein production in lot fed Friesian cows and heifers fed one of four diets. In both studies, the diets varied in the concentration of cereal grains or other high energy constituents. Generating such animal protein in the form of milk protein is 6 to 7 times faster and 2 to 3 times more efficient than retaining protein in the animal carcass. For intensively managed Friesian bulls, this would be equivalent to growth rates of over $6 \mathrm{~kg} / \mathrm{head} /$ day together with double their voluntary feed intakes, both feats physiologically impossible.

Keywords: Feed Efficiency; Protein Utilisation; Meat; Milk

\section{Introduction}

The increasing demand for processed dairy and beef products throughout the developing world and the inability of many of these countries, particularly in the humid tropics of SE Asia, to achieve self-sufficiency in fresh milk and beef production is leading to a re-evaluation of the demand for hence potential imported supplies of, various forms of animal protein. The production cost of such imports from countries with well-established livestock industries, such as Australia, depends greatly on the cost of feed inputs and the efficiency of converting these inputs into saleable animal protein. In addressing this quandary, the following paper, using previously published research data, provides a numerical review on the efficiency of converting high quality feed ingredients into high value sources of animal protein, namely beef and milk solids.

\section{Materials and Methods}

This paper reports on two studies involving Friesian animals. The beef study was undertaken at the Research Institute for Ani- mal Production in at Ciawi in West Java, Indonesia in 1977 and 1978 using high grade Friesian bulls while the dairy study was undertaken at Kyabram Research Institute in Victoria, Australia in 1982 and 1983 with lot fed Friesian dairy cows and heifers.

\section{Beef study}

A total of 25 Friesian bulls were selected from villages in Central Java on the basis of live weight (200 to $250 \mathrm{~kg}$ ) and number of permanent incisor teeth (two to four). In 1977, 11 bulls were fed on a high concentrate ration at Ciawi while in 1978, 14 bulls were fed on a low concentrate ration. Prior to each trial, they were fed ad libitum forage and concentrate for 100 days to reduce the likelihood of compensatory gain during the study. They were individually housed in pens under an insulated roof with continual access to water and feed and rubber mats. In 1977 they were fed a ration comprising ad lib concentrate plus $6 \mathrm{~kg} / \mathrm{head} /$ day of forage, a ration designated as $90 \%$ concentrate. In 1978 they were fed ad lib on 
ration of $70 \%$ forage and $30 \%$ concentrate, on a dry matter basis. The forage was well managed and fertilised Napier grass which was freshly harvested and chopped each day. The concentrate formulation was the same in both trials and was based on wheat pollard and ground maize grain with additional supplements of protein, minerals and vitamins. The crude protein content of the total diets were $14.8 \%$ in the first and $10.7 \%$ on the second trial.

In 1977 the bulls were serially slaughtered on Days 1, 154 or 280 of the feeding period while in 1978 the bulls were serially slaughtered on Days 1, 112 or 224 of the feeding period. In addition to the Friesians, four other Indonesian species of large ruminant bulls (Ongole, Madura, Bali, and swamp buffalo) were also included in the study. Further details of animal feeding and management have been presented by Moran [1].

Following slaughter, the non-carcass components were removed and weighed from each animal. The entire left carcass side was then frozen, ground, mixed and chemically analysed for crude protein, to provide two measures in each trial of efficiency of carcass protein retention, namely between the first and the second slaughter and between the second and the final slaughter of the bulls, as described by Moran [2,3]. The efficiency of protein retention was calculated as g carcass protein per $100 \mathrm{~g}$ dietary protein intake.

\section{Dairy study}

A total of 88 Friesian cows and first lactation heifers were fed total mixed rations (TMR) in two trials during early lactation on one of 4 TMR's based on rolled wheat, whole oats, maize silage and lucerne hay with additional protein, minerals and vitamins. The four TMR's varied in cereal grain content from 0 to $50 \%$ dry matter but were made isonitrogenous at $2.5 \%$ nitrogen (equivalent to $15.6 \%$ protein) by varying the inclusion of urea. In the first 1982 trial, voluntary feed intake, yields of milk and milk solids and changes in live weight were measured in 42 Friesians during early lactation, while in the second 1983 trial, the 46 Friesians were monitored for their entire lactation.

The complete diets were based on blended rolled wheat, whole oats, maize silage, lucerne hay, cottonseed meal, sodium bicarbonate and urea with additional minerals and vitamins. The removal of different amounts of cereal grain (with equal amounts of the rolled wheat and whole oats) were compensated for by increasing the quantities of maize silage in each TMR. Further details of animal management and study results have been presented by Moran and Trigg [4].

In the 1982 trial, 42 Friesians (24 heifers and 18 prior to their second or later lactations) were randomised into four groups on the basis of parity and expected date of calving. Following calving, each animal was group fed ad libitum one of four complete diets for up to 15 weeks, with the last 8 weeks comprising the production trial. The animals averaged $450 \mathrm{~kg}$ live weight and were 45 days post-partum.

All diets were given ad lib such that proportionatly1.15of the previous day's intake was offered. Diets were blended in a mixer wagon and offered daily at 0800 and $1600 \mathrm{hr}$. Residues were collected from each diet group prior to each morning feed and weighed and together with the fresh TMR offered that day, monitored for dry matter concentrations by oven drying at $100 \mathrm{C}$ to constant weight. The diets were also periodically analysed for nitrogen, neutral detergent fibre and starch. Water intakes were measured daily in each yard through metred water troughs.

Milk yields were recorded twice daily and weekly subsamples from a morning and afternoon milking were analysed for milk fat and protein contents. Cows were weighed twice weekly and live weight changes were calculated from regressions of live weight on time.

In the second 1983 trial, 46 Friesians (12 heifers and 34 cows) were randomised into 4 groups on the basis of parity, days postpartum (48 days) and live weight (444 kg). Following calving, all animals were fed for up to 9 weeks on the same diet, with the last 2 weeks designated as a covariate feeding period. Animals were then allocated to one of four diets for a 14 week production trial. Daily feeding management and chemical analyses were the same as those for Trial 1. At the end of this production trial, the animals were allocated to one of two TMR's, differing in quantities of cereal grain and maize silage for the remainder of their lactations. The cows were milked until yields fell below $6 \mathrm{~L} /$ day, they had completed 46 weeks of lactation or were due to calve within the next 6 weeks, whichever occurred earliest. In both trials, the efficiency of protein utilisation for milk protein production was calculated as $\mathrm{g}$ milk protein per $100 \mathrm{~g}$ dietary protein intake. 


\section{Statistical analyses}

For each dairy trial the data on yields of milk, milk protein content and live weight change were subjected to two-way analyses of variance with parity (cows $v$ heifers) and diets as variable factors. The dietary effect was then partitioned into that attributable to linear or quadratic influences. Because the animals were all group fed the TMR's, statistical analyses of feed intake data were not possible.

\section{Results and Discussion}

\section{Beef study}

The data generated in the beef study are presented in table 1. The bulls had higher appetites and growth rates on the $90 \%$ concentrate diet. There were possible subclinical animal health issues with these Friesians during second period of the 30\% concentrate ration which would have adversely affected their growth rates, feed conversion ratios hence efficiencies of carcass protein retention' This conclusion could be made because during this period the Bali bulls in the breed comparative study (of which Friesians were just one of the 5 breeds being studied), all died from a severe viral disease. Therefore it was best to ignore any live animal performance and carcass protein data generated during this period.

Table 1: Production data recorded in the beef study.

\begin{tabular}{|c|c|c|c|c|}
\hline \multirow{2}{*}{$\begin{array}{c}\text { Ration } \\
\text { Days of data collection }\end{array}$} & \multicolumn{2}{|c|}{$90 \%$ concentrate } & \multicolumn{2}{|c|}{$30 \%$ concentrate } \\
\hline & $1-154$ & $154-280$ & $1-112$ & $112-224$ \\
\hline $\begin{array}{c}\text { Dry matter intake } \\
\text { (kg DM/head//day) }\end{array}$ & 7.97 & 9.22 & 7.08 & 7.27 \\
\hline $\begin{array}{l}\text { Average daily gain } \\
\text { (kg/head/day) }\end{array}$ & 0.90 & 1.03 & 0.78 & 0.50 \\
\hline $\begin{array}{c}\text { Estimated metabolisable } \\
\text { energy intake } \\
\left(\mathrm{kJ} / \mathrm{kg}^{0.75} / \text { day }\right)\end{array}$ & 1003 & 941 & 874 & 741 \\
\hline $\begin{array}{c}\text { Feed conversion ratio (kg } \\
\text { daily gain/kg dry } \\
\text { matter intake) }\end{array}$ & 9.3 & 9.0 & 9.5 & 15.8 \\
\hline $\begin{array}{l}\text { Crude protein intake } \\
(\mathrm{kg} / \mathrm{head} / \text { day })\end{array}$ & 1.18 & 1.36 & 0.76 & 0.78 \\
\hline Slaughter live weight (kg) & 510 & 640 & 390 & 450 \\
\hline $\begin{array}{l}\text { Carcass protein retention } \\
(\mathrm{g} / \text { head/day })\end{array}$ & 86 & 98 & 76 & 48 \\
\hline $\begin{array}{l}\text { Efficiency of converting } \\
\text { dietary protein to carcass } \\
\text { protein } \\
\text { (g carcass } / 100 \text { g intake) }\end{array}$ & 7.28 & 7.21 & 10.00 & 6.15 \\
\hline
\end{tabular}

The protein contents of ground carcasses varied from 17.0 to $21.0 \%$ for all 25 Friesian bull carcasses. There was minimal impact of ration quality on carcass protein retention as at mean cold carcass weight of $182 \mathrm{~kg}$, the adjusted mean carcass protein weights were 35.2 and $35.4 \mathrm{~kg}$ respectively for the bulls fed the $90 \%$ and $30 \%$ concentrate rations. However the efficiency of converting dietary protein to carcass protein was found to be $35 \%$ greater during the first period on the $30 \%$ concentrate ration.

The rates of carcass protein retention in the Friesian bulls ranged from a low of 76 to a high of $98 \mathrm{~g}$ /day respectively during these studies. Such levels are only about half of those achievable by young rapidly growing Continental bulls as Robelin., et al. [5] reported $170 \mathrm{~g} /$ day carcass protein retention in Limousins. These Friesians would obviously not have been bred for beef production as intensely as Robelin's continental bulls, although they may have been selected for draught power as well as milk production under traditional production systems as in a developing country such as Indonesia.

\section{Dairy study}

The data generated in the dairy study are presented in table 2 . In both trials, intakes of dry matter and dietary protein were highest on the $30 \%$ cereal grain ration. There were curvilinear relationships between cereal grain content and yields of fat corrected milk (FCM) in both trials whereas with milk protein yield, the relationships were both linear. Dietary effects on milk protein content and live weight change were linear in the second trial. Thomas [6] concluded that once the protein requirements of rumen micro-organisms have been satisfied, additional dietary protein has little effect on milk protein contents and yields, which then respond to increasing supplies of energy yielding constituents, in this case more cereal grain. Although it could not be tested statistically, the efficiency of converting dietary protein to milk protein then increased with increasing cereal grain content.

\section{Concussion}

The most relevant finding in these studies was the comparative conversion of dietary protein to animal protein either in the form of milk or meat. In this study, Australian lot fed Friesian dairy cows produced 560 to 750 (say 600) g/day of milk protein with an ef- 


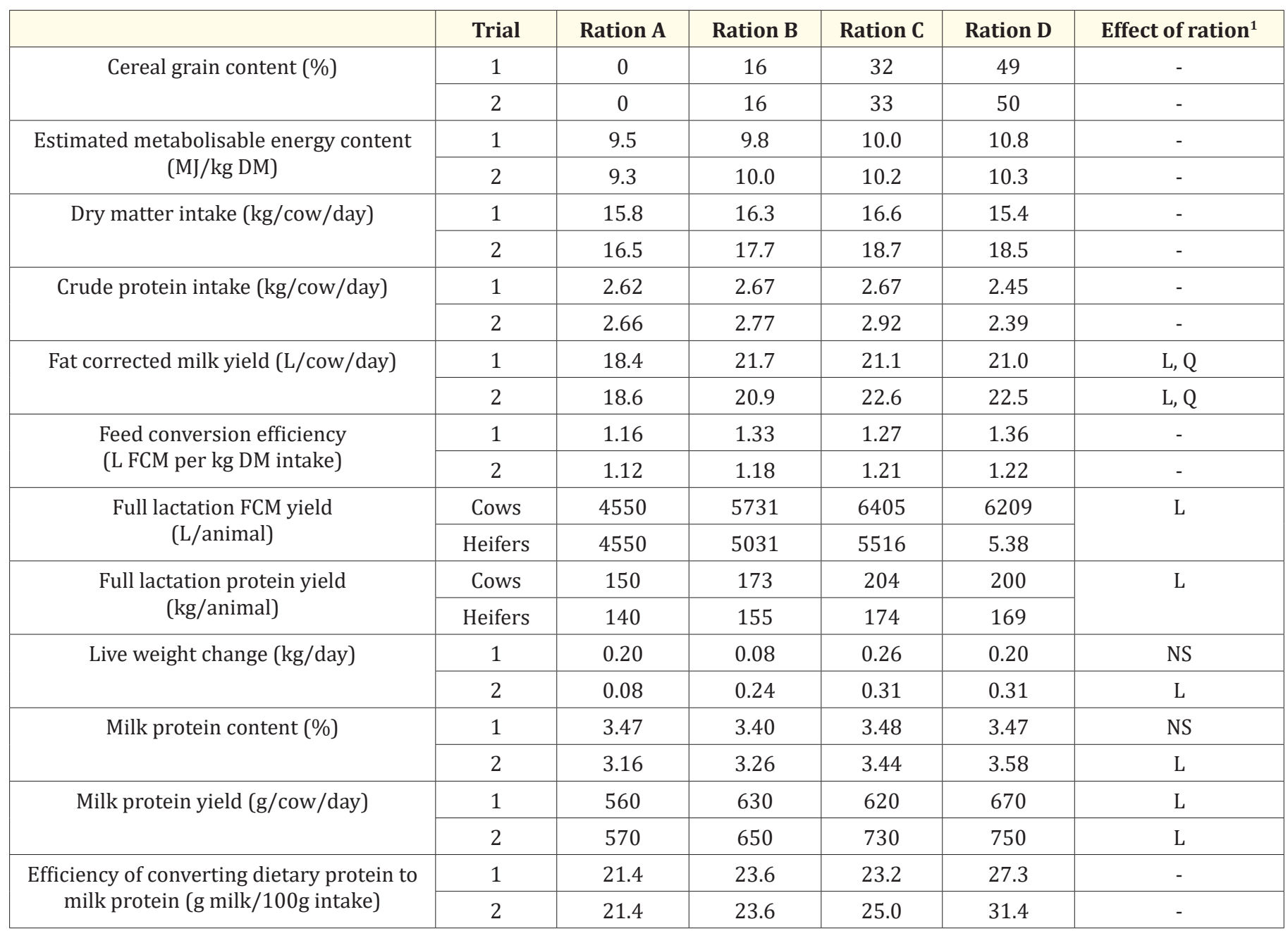

Table 2: Data recorded during each production trial in the dairy study.

${ }^{1} \mathrm{NS}$, no significant effect; L, linear component significant; Q, quadratic component significant $(\mathrm{P}<0.05)$.

ficiency of 20 to 30 (say 25) g milk protein per $100 \mathrm{~g}$ dietary crude protein, depending on the energy content of the TMR. In contrast, well fed and managed Indonesian Friesian bulls were only genetically capable of retaining 76 to 98 (say 90) g/day of carcass protein with an efficiency of 7 to 10 (say 9) g carcass protein per $100 \mathrm{~g}$ dietary protein. In other words, generating animal protein in the form of milk protein is 6 to 7 times faster and 2 to 3 times more efficient than retaining protein in the animal carcass. For intensively managed Friesian bulls, this would be equivalent to growth rates of over $6 \mathrm{~kg} / \mathrm{head} /$ day together with double their voluntary feed intakes, both feats physiologically impossible.

\section{Bibliography}

1. Moran J B. "Comparative performance of five genotypes of Indonesian large ruminants. 1. Effect of dietary quality on live weight and feed utilisation". Australian Journal of Agricultural Research 36 (1983): 743-752.

2. Moran J B. "Comparative performance of five genotypes of Indonesian large ruminants. 2. Growth and development of non-carcass components". Australian Journal of Agricultural Research 36 (1985): 752-763. 
3. Moran J B. "Comparative performance of five genotypes of Indonesian large ruminants. 3. Growth and development of carcass tissues". Australian Journal of Agricultural Research 37 (1986): 435-447.

4. Moran JB and Trigg TE. "Feed intake and utilisation of maize silage-based complete diets by Australian Friesian cows and heifers at various stages of lactation". Livestock Production Science 23 (1989): 275-293.

5. Robelin J., et al. "Changes in body composition of Limousin bulls between 9 and 19 months of age. 2. Chemical composition and calorific value". Annals of Zootechnology (Paris) 28 (1979): 191-208.

6. Thomas P C. "Feeding and milk protein production". In: M.E. Castle and R.G. Gunn (Editors). Milk compositional quality and its importance in future markets, British Society of Animal Production Occasional Publication. No 9 (1984): 53-67.

\section{Assets from publication with us}

- Prompt Acknowledgement after receiving the article

- Thorough Double blinded peer review

- Rapid Publication

- Issue of Publication Certificate

- High visibility of your Published work

Website: www.actascientific.com/

Submit Article: www.actascientific.com/submission.php

Email us: editor@actascientific.com

Contact us: +919182824667

Citation: J B Moran. "Observations on the Influence of Ration Quality on the Efficiency of Dietary Protein Utilisation for Milk Versus Meat Production in Friesians”. Acta Scientific Veterinary Sciences 3.5 (2021): 16-20. 